Sains Malaysiana 46(7)(2017): 1011-1016

http://dx.doi.org/10.17576/jsm-2017-4607-01

\title{
Synthesis of Large-Area Few-Layer Graphene \\ by Open-Flame Deposition
}

(Sintesis Grafin Kawasan Lebar Pelbagai Lapisan melalui Pemendapan Nyalaan Api Terbuka)

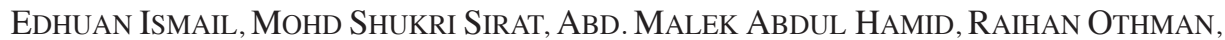 \\ MOHD ASYADI AZAM MOHD ABID \& MOHD HANAFI ANI*
}

\begin{abstract}
Various production methods have been developed for graphene production, but each of them falls short in either the economic or quality aspect. In this paper, we present the flame deposition method, a modified chemical vapor deposition (CVD) that uses an open-flame. In this method, resulting carbon deposits were found to be graphitic in nature, thereby suggesting multilayer graphene growth in a very short reaction time of $5 \mathrm{~min}$. Furthermore, the deposits were transferred onto a cyanoacrylate plastic substrate and its sheet resistance was measured to be $81 \mathrm{ohm} / \mathrm{square}$. The results showed that open-flame deposition exhibits high potential for low-cost, low-energy and high-quality production of graphene.
\end{abstract}

Keywords: Chemical vapor deposition (CVD); graphene; open-flame deposition; plasma; sheet resistance

ABSTRAK

Pelbagai kaedah telah digunakan untuk menghasilkan grafin namun setiap kaedah mempunyai kelemahan sama ada daripada aspek ekonomi atau kualiti. Di sini kami melaporkan kaedah pemendapan wap kimia yang diubah suai dengan kaedah nyalaan api terbuka. Enapan karbon yang terhasil dikenal pasti bersifat grafitik seterusnya mencadangkan pertumbuhan grafin berlapis dalam masa tindak balas yang singkat iaitu 5 min. Kemudian, enapan karbon itu dipindahkan ke atas substrat plastik sianoakrilat dan lapisan rintangan diukur dan nilai rintangannya ialah 81 ohm/persegi. Keputusan menunjukkan bahawa pemendapan api terbuka berpotensi untuk mengeluarkan grafin berkualiti tinggi dengan kos dan penggunaan tenaga yang rendah.

Kata kunci: Grafin; pemendapan nyalaan api terbuka; pemendapan wap kimia (CVD); plasma; rintangan lapisan

\section{INTRODUCTION}

The discovery of graphene has led to an increase in research activities on this so-called wonder material, which possesses unique properties such as high electrical conductivity, optical transparency, high surface area with a theoretical maximum of $2600 \mathrm{~m}^{2} / \mathrm{g}$ and good mechanical strength despite its thinness (Geim \& Novoselov 2007; Lambert et al. 2010; Peigney et al. 2001). In addition, graphene is a highly stable material and this characteristic enables its use for various purposes, from electronics to medical treatments (Kalbacova et al. 2010). Graphene also has high transparency such that a single-layer graphene absorbs only $2 \%$ of visible light; this optical transparency is suitable for photonic and optoelectronic materials (Avouris \& Freitag 2014; Zhao et al. 2014)self-limiting growth of AB-stacked bilayer graphene (BLG. Owing to the aforementioned features, graphene production has attracted significant research attention.

Initially, graphene was synthesized by mechanical cleavage, which led to its discovery in 2004 (Geim \& Novoselov 2007). However, a large-scale production with this method is unviable if the desired product is high-quality graphene with a large-area. The thermal decomposition of metal carbides to grow epitaxial graphene could yield large-area and high-quality graphene, but this approach is costly because it requires metal carbides, such as silicon carbide, as its starting material (Emtsev et al. 2009).

A feasible solution for mass producing large-area, high-quality graphene is derived from chemical vapor deposition (CVD). In fact, several studies reported that graphene films produced by CVD reached 30 inches in size (Bae et al. 2010; Li et al. 2009)graphene is limited to small sizes because it is produced mostly by exfoliating graphite. We grew large-area graphene films of the order of centimeters on copper substrates by chemical vapor deposition using methane. The films are predominantly single-layer graphene, with a small percentage (less than $5 \%$. CVD uses hydrocarbons which are then reduced to graphene on a suitable catalyst substrate. Given that the starting materials are hydrocarbons, CVD is economical in terms of starting materials. However, a typical reaction with CVD requires extreme reaction conditions, thereby complicating the system and resulting in a high-energy process. Many research groups have investigated the synthesis of graphene at extremely high temperature and low reaction pressure (Chen et al. 2015; Polat et al. 2015). Others also reported on using vapor metal as the catalyst for graphene deposition (Murakami et al. 2015). 
Different from the simple flame deposition on copper, such complications prevent CVD from becoming a viable method for the cheap production of graphene (Novoselov et al. 2012).

One of the numerous studies on the improvement of graphene production was via the application of openflame deposition. Similar to plasma-enhanced CVD which was reported by various groups to have improved the resulting graphene (Chan et al. 2013; Jacob et al. 2015), flame is another form of plasma that is expected to exert a similar positive effect on the graphene synthesis. In fact, researchers have reported on the formation of few-layer graphene through open-flame deposition (Li et al. 2011; Liu et al. 2016; Memon et al. 2011). However, Memon et al. (2011) showed that the reaction temperature was still extremely high at $950^{\circ} \mathrm{C}$. Despite so, this is a promising method because markedly simplifies the CVD setup thereby allowing an economical and facile production of graphene. In this study, our group aimed to develop a simple and controlled open-flame synthesis method for large-area and high-quality graphene production.

\section{EXPERIMENTAL DETAILS}

\section{OPEN-FLAME DEPOSITION}

A simple open-flame deposition setup was built from a quartz tube with a ceramic tube as its nozzle as shown in Figure $1 . \mathrm{O}_{2}$ gas was supplied from the nozzle and the rest of the reactant gasses, $\mathrm{CH}_{4}$ and $\mathrm{H}_{2}$ gas with Ar as carrier, were flowed into the reactor from a side inlet. This setup essentially creates an inverse flame when ignition occurs, where $\mathrm{O}_{2}$ comes into the flame center and then reacts to $\mathrm{CH}_{4}$ around it.

A $1 \mathrm{~cm} 1.5 \mathrm{~cm} \mathrm{Cu}$ foil was polished to 1 micron level. Then, the foil was loaded into the reactor for annealing and reduction by $\mathrm{H}_{2}$ gas at $1000^{\circ} \mathrm{C}$ for $20 \mathrm{~min}$. Once done, the substrate was cooled to ambient conditions under Ar flow before the open-flame deposition reaction was initiated. The reaction began by flowing $\mathrm{CH}_{4}$ and $\mathrm{Ar}$ into the reactor first, followed by $\mathrm{O}_{2}$ for the flame. The furnace temperature was set at $750^{\circ} \mathrm{C}$ and the total flow rate was $100 \mathrm{sccm}$ with pressure of $1 \mathrm{~atm}$. The typical reaction time was $5 \mathrm{~min}$; once the reaction was done the sample was left to cool under Ar flow before removal for characterization. Initially, a comparison between openflame deposition and CVD conditions were tested with a 20 min reaction time, as shown in Table 1. Characterization was conducted by optical microscope (Olympus BX41M), Raman spectroscopy (Uniram 5000, wavelength: $532 \mathrm{~nm}$ ) and sheet resistance measurement.

\section{TRANSFER PROCESS}

The carbon deposits were removed from the $\mathrm{Cu}$ substrate by coating cyanoacrylate onto the carbon deposit and then etching away $\mathrm{Cu}$ by using $3 \mathrm{M}$ nitric acid. The procedure is shown in Figure 2. Two types of transfer medium was used; one was cyanoacrylate and the other has tissue added to form a fibre-composite matrix. The sheet resistance of the transferred deposits was measured by using a 4-probe system.

\section{RESULTS AND DISCUSSION}

A comparison between CVD and open-flame deposition shows that flame deposition produces a large amount of carbon, which is observable by the naked eye, whereas the CVD reaction condition did not yield any discernible changes on the $\mathrm{Cu}$ substrate. Furthermore, Raman spectra for both samples and blank $\mathrm{Cu}$ foil were taken for comparison. Reports have noted that although the $\mathrm{Cu}$ substrate fluoresces by itself and produces a background signal, no significant differences were observed compared with the graphene samples transferred onto $\mathrm{SiO}_{2} / \mathrm{Si}$

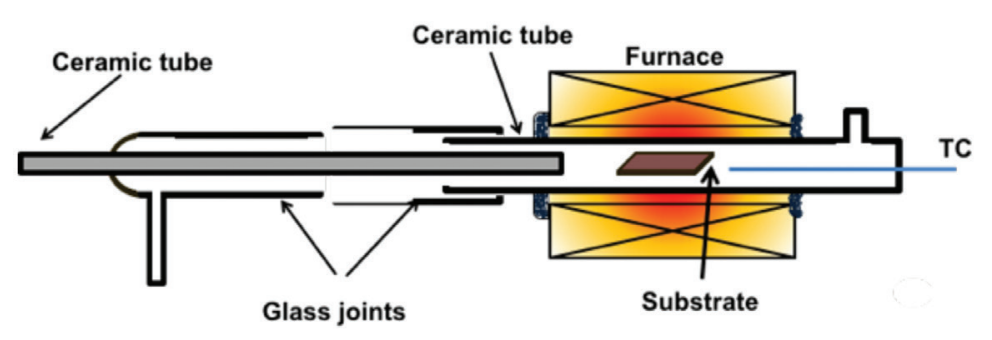

FIGURE 1. Experimental setup for open-flame deposition

TABLE 1. Reaction conditions for CVD and open-flame deposition with a $20 \mathrm{~min}$ reaction at $750^{\circ} \mathrm{C}$

\begin{tabular}{lccc}
\hline \multicolumn{1}{c}{ Condition } & $\begin{array}{c}\mathrm{CH}_{4} \\
/ \mathrm{atm}\end{array}$ & $\begin{array}{c}\mathrm{O}_{2} \\
/ \mathrm{atm}\end{array}$ & $\begin{array}{c}\mathrm{Ar} \\
/ \mathrm{atm}\end{array}$ \\
\hline CVD & 0.3 & - & 0.7 \\
Open-flame deposition & 0.5 & 0.5 & 0.2 \\
\hline
\end{tabular}




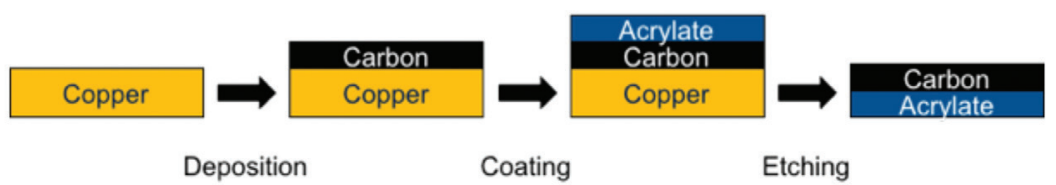

FIGURE 2. Transfer process of deposited carbon onto a cyanoacrylate film

substrates (Costa et al. 2012; Wang et al. 2016)in order to obtain the dependence of the Raman features (intensities, frequencies and line widths. For a reaction temperature of $750^{\circ} \mathrm{C}$ as indicated by the Raman spectra shown in Figure 3, the presence of the flame through the introduction of $\mathrm{O}_{2}$ gas actually promotes the growth of graphitic carbon compared with CVD grown graphene at the same temperature. In comparison of the Raman spectra between the CVD and open-flame deposition, the $\mathrm{D}$ and $\mathrm{G}$ peaks were clearly observed in the open-flame deposition sample but not in the CVD sample.

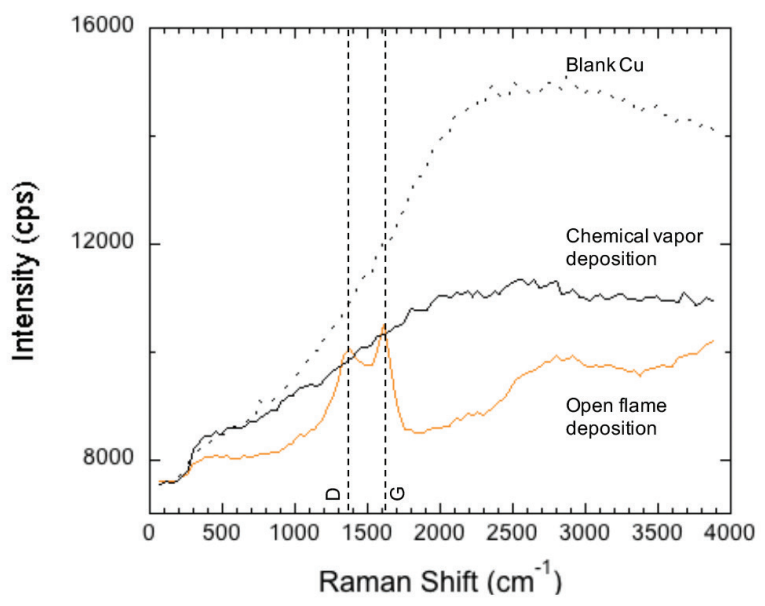

FIGURE 3. Comparison between chemical vapor deposition (0.3 atm $\mathrm{CH}_{4}$, balance $\mathrm{Ar}$ ) and open-flame deposition (0.5 atm $\mathrm{O}_{2}, 0.3 \mathrm{~atm} \mathrm{CH}_{4}$, balance $\left.\mathrm{Ar}\right)$ at $750^{\circ} \mathrm{C}$
Subsequently, various reaction times of 2, 5, 10 and $20 \mathrm{~min}$ were tried and the resulting samples were observed under an optical microscope shown in Figure 4. With increasing reaction time, the deposits darkened because of increasing thickness. Even at $10 \mathrm{~min}$, the copper substrate becomes completely black with carbon deposit, thereby showing that this reaction proceeds at an extremely fast rate. In addition, all samples consistently exhibit parallel straight lines. The periodical formation of this ordered parallel lines showed the crystalline nature of the deposited material, which we believe to be graphitic carbon.

Raman spectra obtained for the samples are shown in Figure 5. For the deposits on the $\mathrm{Cu}$ substrate, peaks observed were D, G, 2D, D+G, and 2D' at 1390, 1600, 2790,2940 and $3100 \mathrm{~cm}^{-1}$. D and $\mathrm{G}$ peaks could be clearly observed, but the intensity of the 2D peak was weak. The appearance of the $\mathrm{D}+\mathrm{G}$ peak was due to defects on the multilayer graphene, thereby suggesting a high degree of amorphization (Cançado et al. 2011). The sample for the 2 min reaction shows displays a massive peak at $\mathrm{D}+\mathrm{G}$.

When the peak ratios for $\mathrm{I}_{\mathrm{D}} / \mathrm{I}_{\mathrm{G}}$ and $\mathrm{I}_{2 \mathrm{D}} / \mathrm{I}_{\mathrm{G}}$ were calculated, as shown in Table 2 , the low $\mathrm{I}_{2 \mathrm{D}} / \mathrm{I}_{\mathrm{G}}$ value (monolayer ratio) ranged from 0.8 to 1.1 . This finding showed that the deposited carbon is multilayer graphene and not monolayer graphene. The defect ratio, $\mathrm{I}_{\mathrm{D}} / \mathrm{I}_{\mathrm{G}}$ was extremely high thereby showing that the resulting multilayer graphene exhibits a high degree of disorder (Wood et al. 2011). Compared with the 20 min reaction, the 5 and 10 min yield a lower $\mathrm{I}_{\mathrm{D}} / \mathrm{I}_{\mathrm{G}}$ ratio, thereby
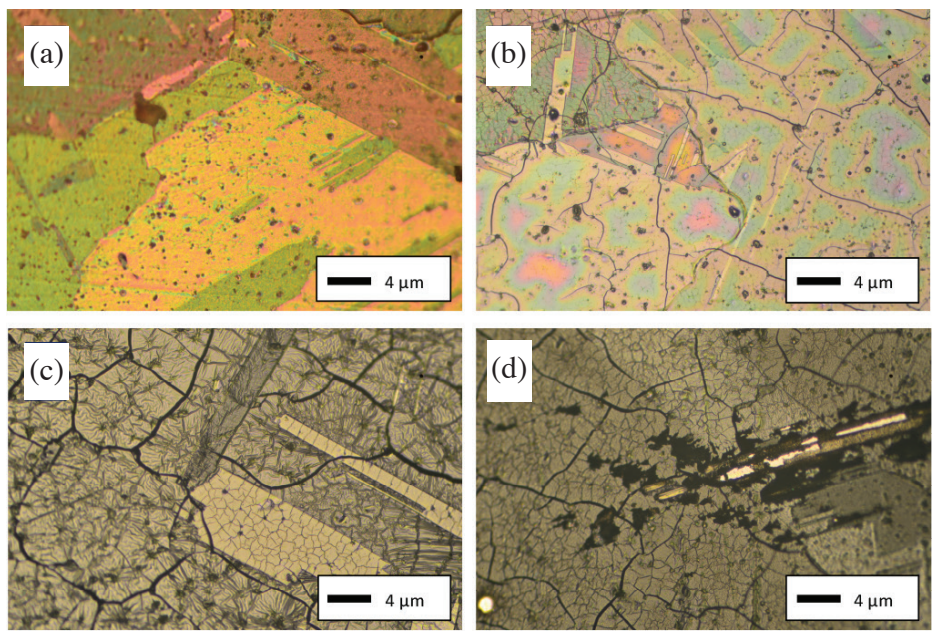

FIGURE 4. Optical microscope images for carbon deposits on $\mathrm{Cu}$ foil by open-flame deposition reaction with reaction time of $2 \mathrm{~min}(\mathrm{a}), 5 \mathrm{~min}(\mathrm{~b}), 10 \mathrm{~min}$ (c) and $20 \mathrm{~min}$ (d) 


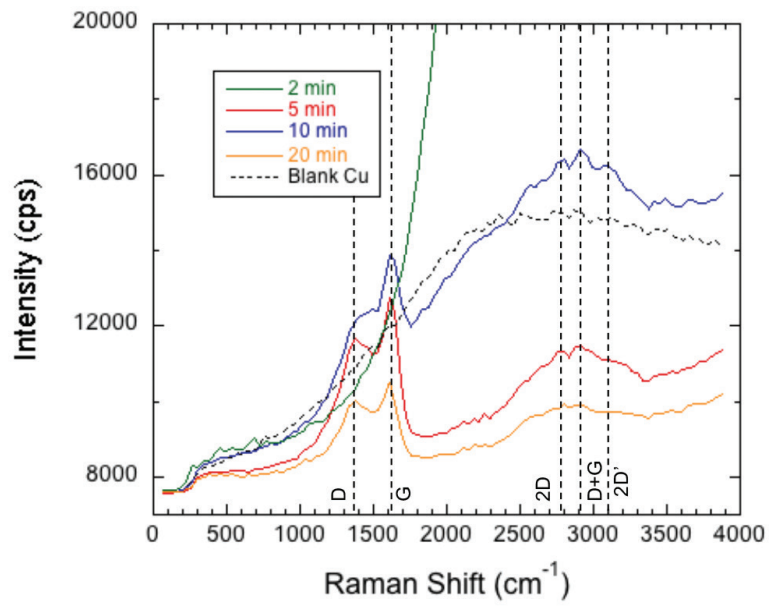

FIGURE 5. Raman spectra for carbon deposits of various reaction times

TABLE 2. Peak ratios of $I_{D} / I_{G}$ and $I_{2 D} / I_{G}$ for various reaction times

\begin{tabular}{ccc}
\hline $\begin{array}{c}\text { Time } \\
\text { /minute }\end{array}$ & $\begin{array}{c}\mathrm{I}_{\mathrm{D}} / \mathrm{I}_{\mathrm{G}} \\
\text { peak ratio }\end{array}$ & $\begin{array}{c}\mathrm{I}_{2 \mathrm{D}} / \mathrm{I}_{\mathrm{G}} \\
\text { peak ratio }\end{array}$ \\
\hline 2 & n.a. & n.a. \\
5 & 0.8991 & 0.8422 \\
10 & 0.8654 & 1.1375 \\
20 & 0.9659 & 0.9301 \\
\hline
\end{tabular}

suggesting that a higher-quality graphene is possible with an even shorter reaction time.

In order to improve the quality of the deposited multilayer graphene, $\mathrm{H}_{2}$ gas was introduced during the reaction at various concentrations. Raman spectra were obtained and the $\mathrm{I}_{\mathrm{D}} / \mathrm{I}_{\mathrm{G}}$ and $\mathrm{I}_{2 \mathrm{D}} / \mathrm{I}_{\mathrm{G}}$ ratios were plotted in Figure 6 . Both $\mathrm{I}_{\mathrm{D}} / \mathrm{I}_{\mathrm{G}}$ and $\mathrm{I}_{2 \mathrm{D}} / \mathrm{I}_{\mathrm{G}}$ ratios display a decreasing pattern with increasing $\mathrm{H}_{2}$ partial pressures. The decrease in the defect ratio shows that hydrogen gas improves the quality of the multilayer graphene. However, lower values for $\mathrm{I}_{2 \mathrm{D}} / \mathrm{I}_{\mathrm{G}}$ indicate the increasing amount of graphene layer; thus, the deposit thickness is actually increasing. According to Memon et al. (2011), the $514 \mathrm{~nm}$ Raman spectroscopy showed that flame-deposited graphene on $\mathrm{Cu}$ yielded $\mathrm{I}_{2 \mathrm{D}} / \mathrm{I}_{\mathrm{G}}$ and $\mathrm{I}_{\mathrm{D}} / \mathrm{I}_{\mathrm{G}}$ ratios of 0.74 and 0.35 for ratio at $950^{\circ} \mathrm{C}$. By comparison, at 0.2 atm $\mathrm{H}_{2}$, the $750^{\circ} \mathrm{C}$ reaction temperature yielded $\mathrm{I}_{2 \mathrm{D}} / \mathrm{I}_{\mathrm{G}}$ and $\mathrm{I}_{\mathrm{D}} / \mathrm{I}_{\mathrm{G}}$ ratios of 0.82 and 0.88 thereby showing that even at temperatures lower than those reported by Memon et al. (2011), we could obtain an even thinner multilayer graphene film but at an increased disorder. Various groups have remarked on the positive effect of hydrogen gas (Vlassiouk et al. 2011; Zhang et al. 2014), which improves the quality of the multilayer graphene; the results of the present study are in accordance with the findings of other researchers. Future studies will test on finding the optimal $\mathrm{H}_{2}$ concentration for the formation of graphene.

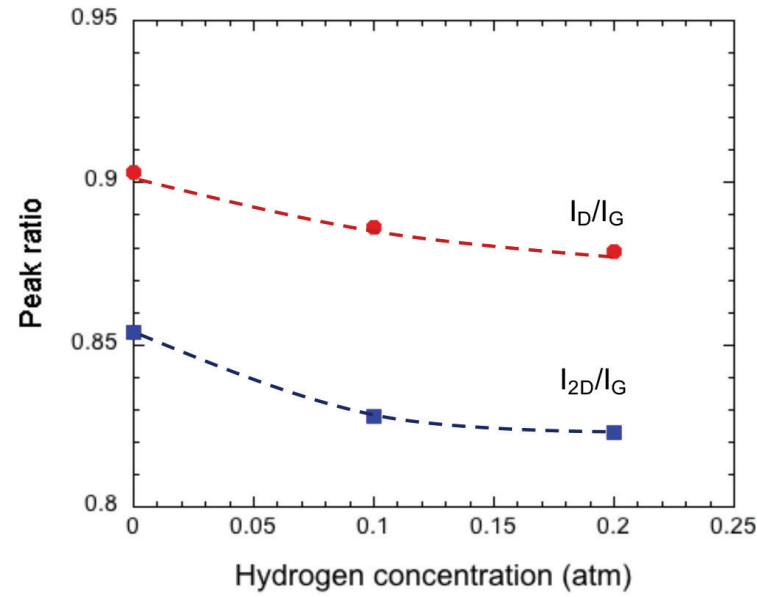

FIGURE 6. Effect of $\mathrm{H}_{2}$ gas partial pressure on $\mathrm{I}_{\mathrm{D}} / \mathrm{I}_{\mathrm{G}}$ and $\mathrm{I}_{2 \mathrm{D}} / \mathrm{I}_{\mathrm{G}}$ peak ratio

Finally, the sheet resistance, of multilayer graphene samples transferred onto cyanoacrylate was measured. The measured sheet resistance values were plotted against the reaction time, as shown in Figure 7. Lower sheet resistance was obtained with increased reaction time. A longer reaction time results in a thicker multilayer graphene deposit and improves conductivity. Based on the conductivity of graphite, $\varrho\left(4 \times 10^{-5} \Omega \cdot \mathrm{cm}\right)$ and based on the sheet resistance equation shown in (1), a reaction time of 20 min presents a sheet resistance of $81 \Omega$ /square, which is equivalent to a sheet thickness, $t$ of $5 \mathrm{~nm}$, thereby translating to approximately 15 layers of graphene. However, based on the Raman spectra, this sample was demonstrated to be highly disordered. Therefore, a markedly thicker disordered graphite is required to achieve this film conductivity. Few-layer graphene obtained by Memon et al. (2011) was reported to possess $40 \mathrm{k} \Omega /$ square sheet resistance at $86 \%$ transmittance.

Multilayer graphene films transferred with only cyanoacrylate displays not only a higher sheet resistance but also a large deviation in sheet resistance, thereby suggesting that the transferred films were badly damaged.

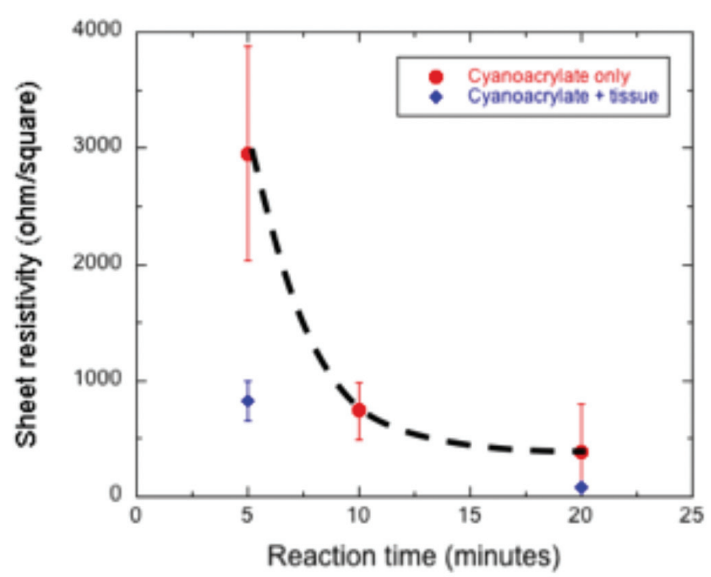

FIGURE 7. Effect of reaction time on sheet resistance 
Incorporating tissue fibers into the cyanoacrylate provides a markedly lowered sheet resistance with a smaller error bar. This result showed that the tissue fibers act as a reinforcement material for the plastic matrix, thereby improving the transfer process. Thus, the damage done onto the multilayer graphene film was significantly reduced similar the result reported by Martins et al. (2013).

\section{CONCLUSION}

We have developed an open-flame deposition method to produce graphene. We found that similar to that obtained through CVD, few-layer graphene could be synthesized at $750^{\circ} \mathrm{C}$, showing its potential for reduced energy consumption in graphene production. Furthermore, this method proceeds at an extremely rapid rate such that a 5 min reaction already yields a multilayer graphene deposit. The addition of $\mathrm{H}_{2}$ gas during the deposition reaction further improves the quality of the multilayer graphene film. Although current samples display a high degree of disorder and thickness, further optimizations conducted to the reaction and transfer process in order to obtain higher-quality graphene. In addition, an in-depth analysis of the reaction kinetics will also be vital to understand the important parameters needed for producing high-quality large-area graphene by using this very simple, low-energy but highly efficient method.

In the future, it is possible to design a conveyer-beltlike continuous graphene production system based on open-flame deposition. This could be easily done because unlike CVD, open-flame deposition does not require a vacuum segment since it could potentially be done in the open ambient pressure.

\section{REFERENCES}

Avouris, P. \& Freitag, M. 2014. Graphene photonics, plasmonics, and optoelectronics. IEEE Journal of Selected Topics in Quantum Electronics 20(1): 72-83. Nature Publishing Group.

Bae, S., Kim, H., Lee, Y., Xu, X., Park, J-S., Zheng, Y., Jayakumar Balakrishnan, Lei, T., Kim, H.R., Song, Y.I., Kim, Y.J., Kim, K.S., Özyilmaz, B., Ahn, J.H., Hong, B.H. \& Iijima, S. 2010. Roll-to-roll production of 30-inch graphene films for transparent electrodes. Nature Nanotechnology 5(8): 574-578.

Cançado, L.G., Jorio, A., Martins Ferreira, E.H., Stavale, F., Achete, C.A., Capaz, R.B., Moutinho, M.V.O., Lombardo, A., Kulmala, T.S. \& Ferrari, A.C. 2011. Quantifying defects in graphene via Raman spectroscopy at different excitation energies. Nano Letters 11(8): 3190-3196.

Chan, S-H., Chen, S-H., Lin, W-T., Li, M-C., Lin, Y-C. \& Kuo, C-C. 2013. Low-temperature synthesis of graphene on $\mathrm{Cu}$ using plasma-assisted thermal chemical vapor deposition. Nanoscale Research Letters 8(1): 285.

Chen, C-C., Kuo, C-J., Liao, C-D., Chang, C-F., Tseng, C-A., Liu, C-R. \& Chen, Y-T. 2015. Growth of large-area graphene single crystals in confined reaction space with diffusiondriven chemical vapor deposition. Chemistry of Materials 27(18): 6249-6258.

Costa, S.D., Righi, A., Fantini, C., Hao, Y., Magnuson, C., Colombo, L., Ruoff, R.S. \& Pimenta, M.A. 2012. Resonant
Raman spectroscopy of graphene grown on copper substrates. Solid State Communications 152(15): 1317-1320.

Emtsev, K.V., Bostwick, A., Horn, K., Jobst, J., Kellogg, G.L., Ley, L., McChesney, J.L., Ohta, T., Reshanov, S.A., Röhrl, J., Rotenberg, E., Schmid, A.K., Waldmann, D., Weber, H.B . \& Seyller, T. 2009. Towards wafer-size graphene layers by atmospheric pressure graphitization of silicon carbide. Nature Materials 8(3): 203-207.

Geim,A.K.\& Novoselov, K.S. 2007. The rise of graphene. Nature Materials 6(3): 183-191.

Jacob, M.V., Rawat, R.S., Ouyang, B., Bazaka, K., Sakthi Kumar, D., Taguchi, D., Iwamoto, M., Neupane, R. \& Varghese, O.K. 2015. Catalyst free plasma enhanced growth of graphene from sustainable sources. Nano Letters 15(9): 5702-5708.

Kalbacova, M., Broz, A., Kong, J. \& Kalbac, M. 2010. Graphene substrates promote adherence of human osteoblasts and mesenchymal stromal cells. Carbon 48(15): 4323-4329.

Lambert, T.N., Luhrs, C.C., Chavez, C.A., Wakeland, S., Brumbach, M.T. \& Alam, T.M. 2010. Graphite oxide as a precursor for the synthesis of disordered graphenes using the aerosol-through-plasma method. Carbon 48(14): 4081-4089.

Li, X., Cai, W., An, J., Kim, S., Nah, J., Yang, D., Piner, R., Velamakanni, A., Jung, I., Tutuc, E., Banerjee, S.K., Colombo,L.\& Ruoff, R.S.2009. Large area synthesis of high quality and uniform graphene films on copper foils. Science 324(5932): 1312-1314.

Li, Z., Zhu, H., Xie, D., Wang, K., Cao, A., Wei, J., Li, X., Fan, L. \& Wu, D. 2011. Flame synthesis of few-layered graphene/ graphite films. Chemical Communications 47(12): 3520.

Liu, H., Zhu, S. \& Jiang, W. 2016. Rapid flame synthesis of multilayer graphene on $\mathrm{SiO}_{2} / \mathrm{Si}$ substrate. Journal of Materials Science: Materials in Electronics 27(3): 27952799.

Martins, L.G.P., Song, Y., Zeng, T., Dresselhaus, M.S., Kong, J. \& Araujo,P.T. 2013. Direct transfer of graphene onto flexible substrates. Proceedings of the National Academy of Sciences 110(44): 17762-17767.

Memon, N.K., Tse, S.D., Al-Sharab, J.F., Yamaguchi, H., Goncalves, A.M.B., Kear, B.H., Jaluria, Y., Andrei, E.Y. \& Chhowal, M. 2011. Flame synthesis of graphene films in open environments. Carbon 49(15): 5064-5070.

Murakami, K., Tanaka, S., Hirukawa, A., Hiyama, T., Kuwajima, T., Kano, E., Takeguchi, M. \& Fujita, J-I. 2015. Direct synthesis of large area graphene on insulating substrate by gallium vapor-assisted chemical vapor deposition. Applied Physics Letters 106: 093112.

Novoselov, K.S., Fal'ko, V.I., Colombo, L., Gellert, P.R., Schwab, M.G. \& Kim, K. 2012. A roadmap for graphene. Nature 490(7419): 192-200.

Peigney, A., Laurent, Ch., Flahaut, E., Bacsa, R.R. \& Rousset, A. 2001. Specific surface area of carbon nanotubes and bundles of carbon nanotubes. Carbon 39(4): 507-514.

Polat, E.O., Balci, O., Kakenov, N., Uzlu, H.B., Kocabas, C. \& Ravinder Dahiya. 2015. Synthesis of large area graphene for high performance in flexible optoelectronic devices. Scientific Reports. www.nature.com/scientificreports. pp. 1-10.

Vlassiouk, I., Regmi, M., Fulvio, P., Dai, S., Datskos, P., Eres, G., Smirnov, S., Vlassiouk, G.E.I., Regmi, M., Fulvio, P., Dai, S. \& Datskos, P. 2011. Role of hydrogen in chemical vapor deposition growth of large single-crystal graphene. ACS Nano 5(7): 6069-6076.

Wang, W., Peng, Q., Dai, Y., Qian, Z. \& Liu, S. 2016. Temperature dependence of Raman spectra of graphene on copper 
foil substrate. Journal of Materials Science: Materials in Electronics 27(4): 3888-3893.

Wood, J.D., Schmucker, S.W., Lyons, A.S., Pop, E. \& Lyding, J.W. 2011. Effects of polycrystalline $\mathrm{Cu}$ substrate on graphene growth by chemical vapor deposition. Nano Letters 11(11): 4547-4554.

Zhang, X., Wang, L., Xin, J., Yakobson, B.I. \& Ding, F. 2014. Role of hydrogen in graphene chemical vapor deposition growth on a copper surface. Journal of the American Chemical Society 136(8): 3040-3047.

Zhao, P., Kim, S., Chen, X., Einarsson, E., Wang, M., Song, Y., Wang, H., Chiashi, S., Xiang, R. \& Maruyama, S. 2014. Equilibrium chemical vapor deposition growth of bernalstacked bilayer graphene. ACS Nano 8(11): 11631-11638.

Edhuan Ismail, Mohd Shukri Sirat, Abd. Malek Abdul Hamid, Raihan Othman \& Mohd Mohd Hanafi Ani*

Department of Manufacturing and Materials Engineering International Islamic University Malaysia (IIUM)

Jalan Gombak, 53100 Kuala Lumpur

Malaysia
Asyadi Azam Mohd Abid Engineering Materials Department Faculty of Manufacturing Engineering Universiti Teknikal Malaysia Melaka (UTeM) Durian Tunggal, 76100 Melaka

Malaysia

*Corresponding author; email: mhanafi@iium.edu.my

Received: 14 October 2016

Accepted: 13 January 2017 